\title{
Morphometric Analysis of a Drainage Basin using Remote Sensing and Geographical Information System (GIS)
}

\author{
Shruti Verma*, Dhiraj Khalkho and Lov Kumar Gupta \\ Department of Soil and Water Engineering, Indira Gandhi Krishi Vishwavidyalaya, \\ Raipur - 492012, Chhattisgarh, India \\ *Corresponding author
}

\begin{tabular}{|l|}
\hline K e y w o r d s \\
Morphometric, \\
GIS, DEM, \\
Watershed, \\
Remote sensing \\
\hline Article Info \\
\hline $\begin{array}{l}\text { Accepted: } \\
\text { 15 March } 2020 \\
\text { Available Online: } \\
\text { 10 April 2020 }\end{array}$ \\
\hline
\end{tabular}

\section{A B S T R A C T}

\begin{abstract}
Morphometric analysis is important in any hydrological investigation and it is inevitable in development and management of drainage basin. Geographical Information System and image processing techniques can be employed for the identification of morphological features and analyzing properties of basin. The morphometric parameters of basin can address linear, areal and relief aspects. Database has been prepared in ArcGIS 10.5 desktop application for certain significant of morphometric parameters analysis. The Shuttle Radar Topography Mission (SRTM) 30 meter data were used for preparation of DEM, and drainage network. Study area is Maniari sub-watershed, geographically located

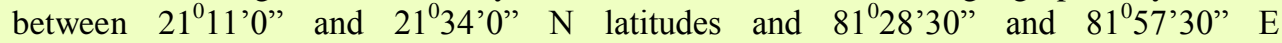
longitudeslocated in Mungeli district of Chhattisgarh state in India. The Maniari subwatershed covers an area of about $31.33 \mathrm{~km}^{2}$ and has $4^{\text {th }}$ order streams were calculated by using GIS environment. Total number of streams were 114, in which 90 was found to be in first order, 19 was in second order, 4 was in third order and 1 was in fourth order streams. The length of stream segment is maximum for first order stream and decreases as the stream order increases. The drainage density $\left(D_{d}\right)$ of study area was $1.684 \mathrm{~km} \mathrm{~km}^{-2}$. This study would help the local people to utilize the resources for sustainable development of the basin area.
\end{abstract}

\section{Introduction}

In countries like India, where the population pressure is constantly rising land and water resources are limited and their wide utilization is imperative. The drainage basins, catchments and sub-catchments are the basic units for the management of natural resources for administrative purposes. Morphometry is the calculation and mathematical study of the form, shape and structure of the earth (Clarke, 1996; Agarwal, 1998). Development of a drainage system and the flowing pattern of a river over space and time are influenced by several variables such as geology, geomorphology, structural components, soil, and vegetation of the area through which it flows. Geographical Information System 
(GIS) techniques have been used for assessing various terrain and morphometric parameters of the drainage basins and watersheds as they provide a flexible environment and a powerful tool for the manipulation and analysis of the spatial information, particularly for the future identification and extraction of the information for better understanding (Vijith, 2006).

The morphometric study of the drainage basin and channel network plays a vital role in understanding the drainage basin geohydrological behavior and expresses the prevailing climate, geology, geomorphology, structural, etc. antecedents of the catchment. Watershed management process implies appropriate use of land and water resources for optimum production with minimum hazard to natural resources (Nag, 1998; Kanth et al., 2012).

Morphometric analysis can be done by measuring linear and shape of drainage network Biswas et al., (1999), Javed et al., (2011), Patel et al., (2013).

Thematic layers are prepared by the application of remote sensing for morphometric analysis. Morphometric analysis provides the geometry of basin which provides the understanding of geometric and geological history of drainage basin (Strahler, 1957).

The main objectives of this work was to performed morphometric analysis of Maniary sub-watershed and find out their different characteristic with the help of various parameter viz., streams number, streams order, streams length, mean streams length, bifurcation ratios, circularity ratio, elongation ration, relief ratio, shape factor, drainage density, stream frequency, length of overland flow, constant channel maintenance, texture ratio, etc. using the remote sensing and GIS.

\section{Materials and Methods}

\section{Description of study area}

Maniari watershed is situated in Lormi block of Mungeli district and located between $21^{0} 11^{\prime} 0$ "'and $21^{0} 34^{\prime} 0 " \mathrm{~N}$ latitudes and $81^{0} 28$ '30" and $81^{\circ} 57^{\prime} 30^{\prime \prime}$ E longitude (Fig. 1). Maniari watershed is covered by topographic map No. (64 F/6, 64 F/7, 64 F/10, 64 F/11, 64 F/12, 64 F/14, 64 F/15, and 64 F/16). The Maniari watershed covers geographical area of $1067.63 \mathrm{~km}^{2}$. In Maniari watershed having 17 sub-watersheds, out of this the study were carried out for the sub-watershed no. $4 \mathrm{G} 3 \mathrm{~F} 4 \mathrm{n}$ which covers $31.33 \mathrm{~km}^{2}$ area.

\section{Database and methodology}

The base map has prepared from topographic map with scale 1:50000 Topographical maps were rectified/referenced geographically and mosaicked and entire study area was delineated in GIS environment with the help of Arc-GIS 10.5 software assigning Universal Transverse Mercator (UTM), World Geodetic System (WGS dating from 1984). SRTM (30 $\mathrm{m})$ data was used in this study to extract drainage network and analysis of Morphometric parameters. Hydrology tool under Spatial Analyst Tools in ArcGIS10.5 software was used to extract drainage channels that followed a series of steps i.e. DEM, fill, flow accumulation, stream order and drainage network. The definition of different morphometric parameters used in the study and empirical formulas are presented in Table 1.

\section{Results and Discussion}

\section{Morphometric characteristics}

The various morphometric parameters such as stream length, bifurcation ratio, drainage density, stream frequency, form factor, 
texture ratio, elongation ratio, circularity ratio, compactness constant etc. were computed.

\section{Linear aspects of the basin}

\section{Stream order}

Stream ordering is the first step of quantitative analysis of the watershed. The designation of stream orders is the first step in drainage analysis and is based on hierarchic ranking of streams. In the present study, ranking of the streams is carried out based on the method proposed by Strahler (1964). The order of the basin is the order of the highest stream. In the present case study, the watershed is of 4 th order. It was found that as the stream order increases the frequency decreases.

\section{Stream number $\left(\mathbf{N}_{\mathrm{u}}\right)$}

Stream number is the number of stream segments of various orders. It is inversely proportional to the stream order. ArcGIS 10.5 was used for calculating steam number. Total 114 no of streams were identified out of which 90 was found to be in first order, 19 was in second order, 4 was in third order and 1 was in fourth order respectively. The higher amount of stream order indicates lesser permeability and infiltration (Strahler, 1964).

\section{Bifurcation ratio $\left(\mathbf{R}_{\mathrm{b}}\right)$}

The bifurcation ratio is dimensionless property, defined as ratio of number of streams in $\mathrm{N}^{\text {th }}$ order to $(\mathrm{N}+1)^{\text {th }}$ order (Horton, 1945). It is an important parameter to describing stages of a river development. Lower value of the $R_{b}$ is characteristics of basin which have suffered less structural disturbances (Strahler, 1964). Bifurcation ratio values for the Maniarisub-watershed of 4.70 .

\section{Stream length $\left(\mathbf{L}_{\mathbf{u}}\right)$}

Total stream length is the length of all the streams having order $\mathrm{u}$. It is indicative of the contributing area of the basin of that order. The stream length of different order wise was computed based on the law proposed by Horton (1945). The stream length of study area is $52.79 \mathrm{~km}$.

\section{Length of overland flow $\left(\mathrm{L}_{\mathrm{g}}\right)$}

It is the largest length of the flow stream from the starting point of runoff water up to that point of the catchment where runoff is not available to flow the outlet. The length of overland flow $\left(\mathrm{L}_{\mathrm{g}}\right)$ approximately equals to half of the reciprocal of drainage density (Horton, 1945).The length of overland flow of Maniari sub-watershed is 0.84 kilometers.

\section{Aerial aspect of drainage basin}

\section{Basin area (A)}

Basin area is the direct outcome of the drainage development in a particular basin. The rate of runoff depends on its area and physiography. Larger the area, smaller is the runoff and vice versa.

\section{Perimeter (P)}

Length boundary of a basin is known as the perimeter of the basin. The basin parameter dependent on elongation ratio and circulatory ratio.

\section{Drainage density $\left(D_{d}\right)$}

Drainage density is defined as a ratio of total length of all streams to the total area of the basin. Horton (1932) introduced drainage density into literature as an expression to indicate the closeness of spacing of channels. The measurement of $D_{d}$ is a useful numerical 
measure of landscape dissection and runoff potential (Chorley et al., 1957). In general, low values of $D_{d}$ indicate that the regions underlain by highly permeable material with vegetative cover and low relief and vice versa (Nautiyal, 1994). The drainage density of the Maniari sub-watershed was found to be 1.68 $\mathrm{km} / \mathrm{km}^{2}$.

\section{Stream frequency $\left(F_{\mathrm{s}}\right)$}

The stream frequency is the number of streams per unit area of the basin. It mainly depends upon the lithology of the basin and reflects the texture of the drainage network. It is a good indicator of drainage pattern. The stream frequency $\left(\mathrm{F}_{\mathrm{s}}\right)$ of the whole basin was found 3.63 .

\section{Texture ratio $\left(\mathbf{R}_{t}\right)$}

It is the total number of stream segment of all orders per perimeter of that area (Horton, 1945). Horton recognized infiltration capacity as the single important factor which influences Texture ratio $\left(\mathrm{R}_{\mathrm{t}}\right)$ and considered the drainage texture to include drainage density and drainage frequency. Table 2 shows that in Texture ratio (Rt) of the study area was found to be 1.13 .

\section{Circularity ratio $(\mathbf{R c})$}

It is the ratio of area of the basin to the area of circle having the same circumference as the perimeter (P) of the basin (Miller, 1953).High circularity ratio reflects rapid discharge from the watershed and watershed of low circularity ratio have high channel storage and low sediment yield-delivery ratio (Singh, 1992). It was found to be 0.18 in Maniari subwatershed.

\section{Form factor $\left(\mathbf{R}_{\mathbf{f}}\right)$}

It is defined as the ratio of basin area to square of the basin length (Horton, 1932). The form factor ratio value of the basin was low, 0.04 .

\section{Elongation ratio $\left(\mathbf{R}_{\mathbf{e}}\right)$}

Elongation ratio is defined as the ratio of diameter of a circle of the same area as the basin to the maximum basin length (Schumm, 1964). The value of $R_{e}$ for the Maniari subwatershed was found to be 2.86 . The $\mathrm{R}_{\mathrm{e}}$ values can be grouped into three categories, namely circular (>0.9), oval (0.8-0.9), less elongated $(<0.7)$ (Chopra, et al., 2005). The results indicate that basin is circular. Values near to 1.0 are typical of regions of very low relief (Strahler, 1964).

\section{Aspects of drainage basin Maximum watershed relief $(H)$}

It is the maximum vertical distance between the lowest and highest points of watershed. It is also known as total relief.

\section{Relief ratio $\left(\mathbf{R}_{h}\right)$}

It is the total relief $(\mathrm{H})$ of watershed divided by maximum basin length $\left(\mathrm{L}_{\mathrm{b}}\right)$. It is an indicator of potential energy available to move water and sediment down the slope. The $\mathrm{R}_{\mathrm{h}}$ normally increases with decreasing drainage area and size of watersheds of a given drainage basin (Gottschalk, 1964). Relief ratio measures the overall steepness of a drainage basin and is an indicator of the intensity of erosion process operating on slope of the basin (Schumm, 1956).

\section{Ruggedness number $\left(\mathbf{R}_{\mathbf{n}}\right)$}

Ruggedness number is the product relief of basin $(H)$ and drainage density $\left(D_{d}\right)$. It gives an idea of overall roughness of watershed. The Ruggedness Number of the Maniari subwatershed was 0.081 to be indicating that low value of ruggedness and basin implies that area is less prone to soil erosion and have 
intrinsic structural complexity in association with relief and drainage density.

\section{Relative relief $\left(\mathbf{R}_{\mathbf{r}}\right)$}

It is the ratio of the maximum watershed relief to the perimeter of the watershed. Morphological characteristic of a catchment was derived manually from topographic map of the watershed and Geographical
Information System (GIS). In the study area, the value of relief ratio was 1.02 .

\section{Compactness constant $\left(\mathbf{C}_{c}\right)$}

The $\mathrm{C}_{\mathrm{c}}$ is independent of size of basin and dependent only on the shape. The compactness coefficient for study area was found to be 2.35 .

Table.1 Empirical relationships used in analysis of morpho-metric parameters and formula

\begin{tabular}{|c|c|c|}
\hline $\begin{array}{l}\text { Morphometric } \\
\text { parameter }\end{array}$ & Formula & Reference \\
\hline \multicolumn{3}{|l|}{ Linear Aspects } \\
\hline Stream order & Hierarchial rank & Strahler (1964) \\
\hline Stream length $\left(\mathbf{L}_{\mathbf{u}}\right)$ & Length of stream & Horton (1945) \\
\hline $\begin{array}{l}\text { Mean stream length } \\
\left(\mathbf{L}_{\mathrm{sm}}\right)\end{array}$ & $\begin{array}{l}\mathrm{L}_{\mathrm{sm}}=\mathrm{L}_{\mathrm{u}} / \mathrm{N}_{\mathrm{u}} \\
\text { where, } \mathrm{L}_{\mathrm{sm}}=\text { mean stream length } \\
\mathrm{L}_{\mathrm{u}}=\text { Total stream length of order ' } \mathrm{u} \text { ' } \\
\mathrm{N}_{\mathrm{u}}=\text { Total no. of stream segments of order ' } \mathrm{u} \text { ' }\end{array}$ & Strahler, 1964) \\
\hline $\begin{array}{l}\text { Stream length ratio } \\
\left(\mathbf{L}_{\mathrm{ur}}\right)\end{array}$ & $\begin{array}{l}\mathrm{L}_{\mathrm{ur}}=\mathrm{L}_{\mathrm{u}} / \mathrm{L}_{\mathrm{u}-1} \\
\text { where, } \mathrm{L}_{\mathrm{ur}}=\text { stream length ratio } \\
\mathrm{L}_{\mathrm{u}}=\text { mean of stream length of order ' } \mathrm{u} \text { ' } \\
\mathrm{L}_{\mathrm{u}-1}=\text { mean of stream length of its next lower order }\end{array}$ & Horton (1945) \\
\hline $\begin{array}{l}\text { Bifurcation ratio } \\
\left(\mathbf{R}_{\mathbf{b}}\right)\end{array}$ & $\begin{array}{l}\mathrm{R}_{\mathrm{b}}=\mathrm{N}_{\mathrm{u}} / \mathrm{N}_{\mathrm{u}+1} \\
\mathrm{R}_{\mathrm{b}}=\text { Bifurcation ratio } \\
\mathrm{N}_{\mathrm{u}}=\text { Total no. of stream segments of order ' } \mathrm{u} \text { ' } \\
\mathrm{N}_{\mathrm{u}+1}=\text { no. of stream segments of the next higherorder }\end{array}$ & Schumn (1956) \\
\hline $\begin{array}{l}\text { Mean bifurcation } \\
\text { ratio }\left(\mathbf{R}_{\mathrm{bm}}\right)\end{array}$ & $\mathrm{R}_{\mathrm{bm}}=$ Average of bifurcation ratios of all orders & Strahler (1957) \\
\hline $\begin{array}{l}\text { Length of overland } \\
\text { flow }\left(L_{g}\right)\end{array}$ & $\begin{array}{l}L_{g}=1 / 2 D_{d} \\
\text { where, } L_{g}=\text { Length of overland flow } \\
D_{d}=\text { Drainage density }\end{array}$ & Horton (1945) \\
\hline Basin length $\left(\mathbf{L}_{\mathbf{b}}\right)$ & $\begin{array}{l}L_{b}=1.321 A 0.568 \\
\text { where, } A=\text { Area of the basin }\end{array}$ & Nookaratnam (2005) \\
\hline Basin Perimeter $(\mathbf{P})$ & $\begin{array}{l}\text { Outer boundary of drainage basin measured in } \\
\text { kilometers. (GIS software analysis) }\end{array}$ & Schumn(1956) \\
\hline \multicolumn{3}{|l|}{ Areal Aspects } \\
\hline $\begin{array}{l}\text { Drainage density } \\
\left(D_{d}\right)\end{array}$ & $\begin{array}{l}D_{d}=L_{u} / A \\
\text { where, } D_{d}=\text { Drainage density } \\
L_{u}=\text { Total stream length of all orders } \\
A=\text { Area of basin }\left(\mathrm{km}^{2}\right)\end{array}$ & Horton (1945) \\
\hline Basin Area (A) & Area from which water drains to a common stream. & Strahler (1964) \\
\hline
\end{tabular}




\begin{tabular}{|c|c|c|}
\hline & (GIS software analysis) & \\
\hline $\begin{array}{l}\text { Stream frequency } \\
\left(\mathbf{F}_{\mathrm{s}}\right)\end{array}$ & $\begin{array}{l}F_{s}=N_{u} / A \\
\text { where } F_{s}=\text { Stream frequency } \\
N_{u}=\text { Total no. of streams of all orders } \\
A=\text { Area of basin }(\mathrm{km} 2)\end{array}$ & Horton (1932) \\
\hline Texture ratio $\left(\mathbf{R}_{t}\right)$ & $\begin{array}{l}\mathrm{R}_{\mathrm{t}}=\mathrm{N}_{\mathrm{u}} / \mathrm{p} \\
\text { where, } \mathrm{R}_{\mathrm{t}}=\text { Texture ratio } \\
\mathrm{Nu}=\text { Total no. of streams of all orders } \\
\mathrm{P}=\text { Perimeter }(\mathrm{km})\end{array}$ & Horton (1945) \\
\hline $\begin{array}{l}\text { Infiltration Number } \\
\left(\mathbf{I}_{\mathbf{f}}\right)\end{array}$ & $\begin{array}{l}D_{d} \times F_{s} \\
\text { Where, } D_{d}=\text { Drainage density }\left(\mathrm{Km} / \mathrm{Km}^{2}\right) \text { and } F_{s}= \\
\text { Drainage frequency. }\end{array}$ & Zavoiance (1985) \\
\hline Form factor $\left(\mathbf{R}_{\mathbf{f}}\right)$ & $\begin{array}{l}\mathrm{R}_{\mathrm{f}}=\mathrm{A} / \mathrm{L}_{\mathrm{b}}{ }^{2} \\
\text { where, } \mathrm{A}=\text { Area of basin }(\mathrm{km} 2) \\
\mathrm{L}_{\mathrm{b}}{ }^{2}=\text { Square of basin length }\end{array}$ & Horton (1932) \\
\hline Shape factor $\left(B_{s}\right)$ & $\begin{array}{l}\mathrm{B}_{\mathrm{s}}=\mathrm{L}_{\mathrm{b}}^{2} / \mathrm{A} \\
\text { where, } \mathrm{L}_{\mathrm{b}}=\text { Square of basin length } \\
\mathrm{A}=\text { Area of basin }\left(\mathrm{km}^{2}\right)\end{array}$ & Nookaratnam (2005) \\
\hline $\begin{array}{l}\text { Circulatory ratio } \\
\left(\mathbf{R}_{\mathbf{c}}\right)\end{array}$ & $\begin{array}{l}\mathrm{R}_{\mathrm{c}}=4 \times \pi \times \mathrm{A} / \mathrm{P}^{2} \\
\text { where, } \mathrm{R}_{\mathrm{c}}=\text { circulatory ratio } \\
\mathrm{A}=\text { Area of basin }\left(\mathrm{km}^{2}\right) \\
\mathrm{P}=\text { Square of the perimeter }(\mathrm{km})\end{array}$ & Miller (1953) \\
\hline Elongation ratio $\left(\mathbf{R}_{\mathrm{e}}\right)$ & $\begin{array}{l}\mathrm{R}_{\mathrm{e}}=(4 \mathrm{xA} / \pi) 0.5 / \mathrm{L}_{\mathrm{b}} \\
\text { where, } \mathrm{R}_{\mathrm{e}}=\text { Elongation Ratio } \\
\mathrm{A}=\text { Area of basin }\left(\mathrm{km}^{2}\right) \\
\mathrm{L}_{\mathrm{b}}=\text { Basin length }\end{array}$ & Schumn (1956) \\
\hline $\begin{array}{l}\text { Compactness } \\
\text { constant }\left(\mathbf{C}_{c}\right)\end{array}$ & $\begin{array}{l}\mathrm{C}_{\mathrm{c}}=0.2821 \mathrm{P} / \mathrm{A} 0.5 \\
\text { where, } \mathrm{A}=\text { Area of basin }\left(\mathrm{km}^{2}\right) \\
\mathrm{P}=\text { Perimeter }(\mathrm{km})\end{array}$ & Horton (1945) \\
\hline $\begin{array}{l}\text { Constant channel } \\
\text { maintenance }(C)\end{array}$ & $\begin{array}{l}\mathrm{C}=1 / \mathrm{D}_{\mathrm{d}} \\
\text { where, } \mathrm{D}_{\mathrm{d}} \text { Drainage density }\end{array}$ & Schumn (1956) \\
\hline \multicolumn{3}{|l|}{ ReliefAspects } \\
\hline $\begin{array}{l}\text { Ruggedness Number } \\
\left(\mathbf{R}_{\mathbf{n}}\right)\end{array}$ & $\begin{array}{l}\mathrm{R}_{\mathrm{n}}=\mathrm{D}_{\mathrm{d}} *(\mathrm{H} / 1000) \\
\mathrm{R}_{\mathrm{n}}=\text { Ruggedness number } \\
\text { where, } \mathrm{D}_{\mathrm{d}}=\text { Drainage density and } \\
\mathrm{H}=\text { Basin relief }(\mathrm{m})\end{array}$ & Strahler (1956) \\
\hline Relief Ratio & $\begin{array}{l}\mathrm{R}_{\mathrm{hl}}=\mathrm{H} / \mathrm{L}_{\mathrm{b}} \\
\mathrm{R}_{\mathrm{hl}}=\text { Relief ratio } \\
\text { where,H=Basin relief }(\mathrm{m}) \text { and } \mathrm{L}_{\mathrm{b}}=\text { Basin length }\end{array}$ & Schumn (1956) \\
\hline
\end{tabular}


Table.2 Morphometric analysis of the study area

\begin{tabular}{|c|c|}
\hline Morphometric parameters & Value \\
\hline Basin Area (sq. Km) & 31.33 \\
\hline Total Number of Stream (Nu) & 114 \\
\hline Perimeter(P), (Km.) & 46.72 \\
\hline Basin Length (Lb), (Km.) & 2.20 \\
\hline Elongation Ratio (Re) & 2.86 \\
\hline Texture Ratio $\left(\mathbf{R}_{\mathrm{t}}\right)$ & 1.13 \\
\hline Mean Bifurcation Ratio (Rbm) & 4.70 \\
\hline Drainage density $(\mathrm{D}),(\mathrm{Km} / \mathrm{Km} 2)$ & 1.68 \\
\hline Stream frequency $\left(F_{s}\right)$ & 3.63 \\
\hline Form factor(Rf) & 6.44 \\
\hline Circulatory ratio(Rc) & 0.18 \\
\hline $\begin{array}{l}\text { Length of overland flow }(\mathrm{Lg}) \text {, } \\
(\mathrm{Km} .)\end{array}$ & 0.84 \\
\hline Constant channel maintenance $(C)$ & 0.59 \\
\hline Compactness constant $\left(\mathrm{C}_{\mathrm{c}}\right)$ & 2.35 \\
\hline Shape factor $\left(B_{s}\right)$ & 0.15 \\
\hline Ruggedness Number & 0.08 \\
\hline Basin Relief (H), (m.) & 48.00 \\
\hline Relief Ratio (Rh) & 1.02 \\
\hline
\end{tabular}

Figure.1 Location map of study area
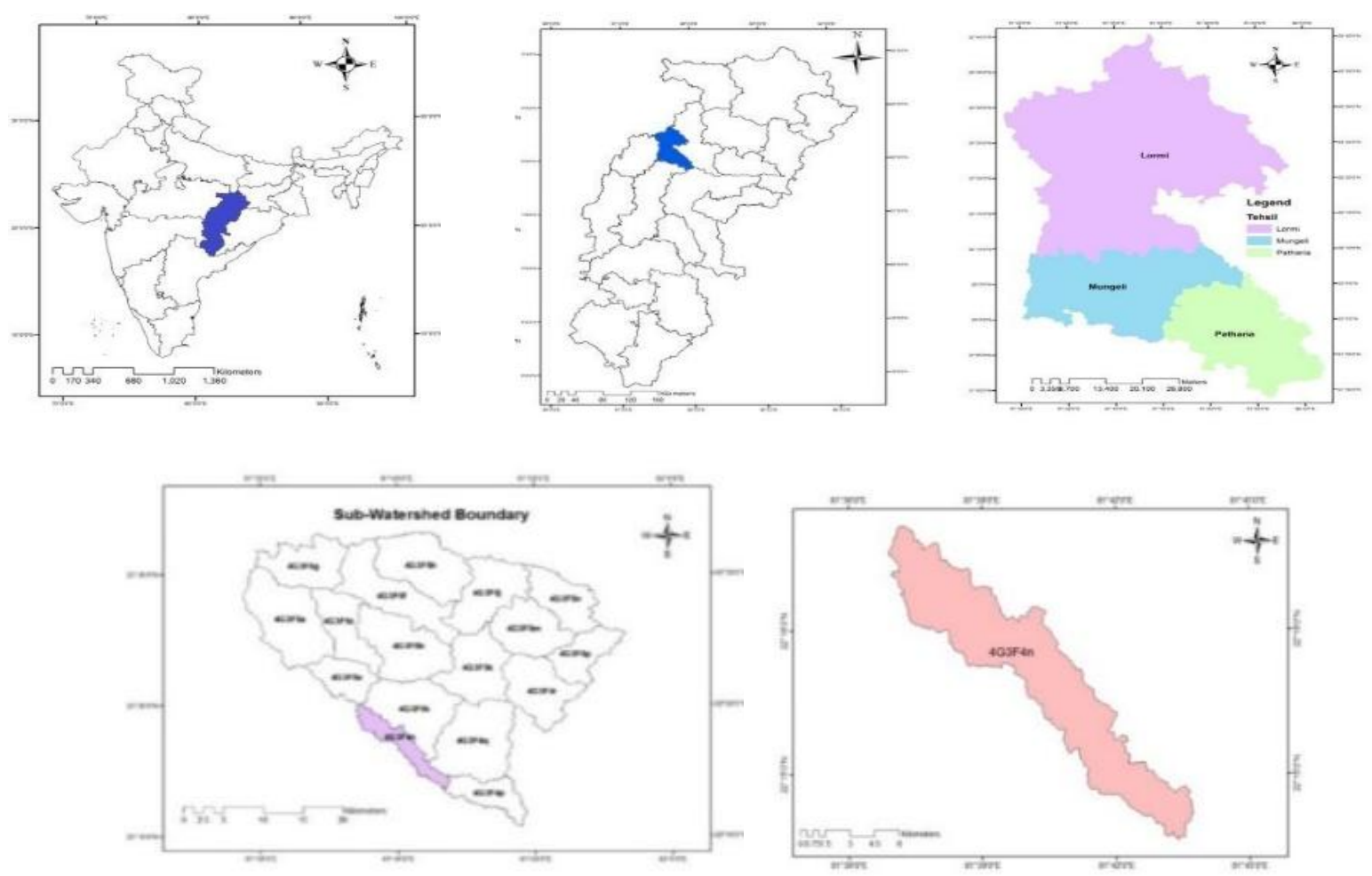
Figure.2 Extraction of drainage network of the study area of Maniari sub-watershed
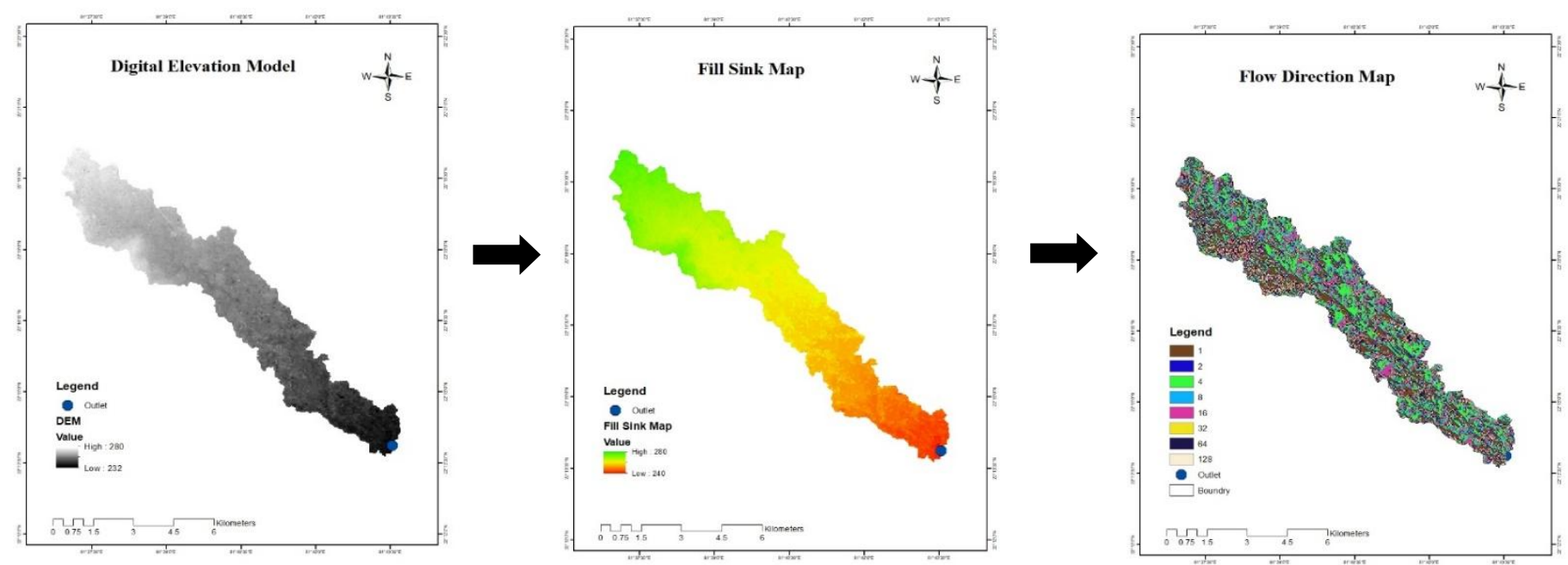

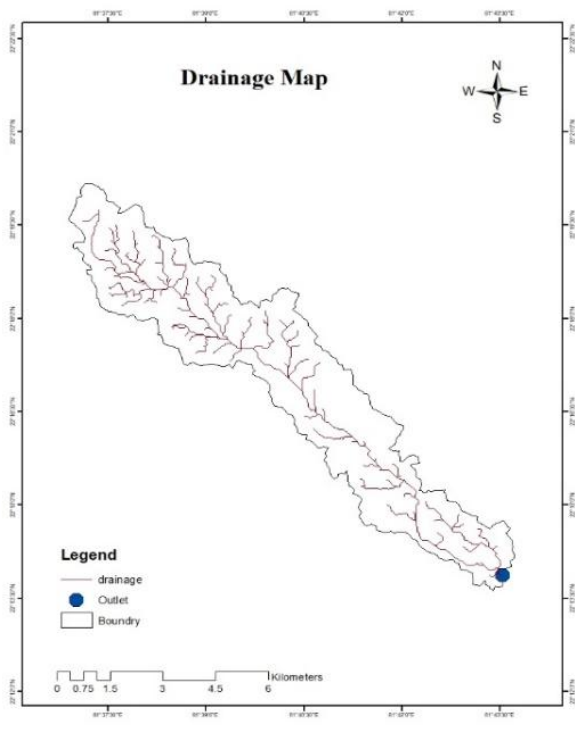

\section{Constant of channel maintenance (C)}

Schumn (1956) used the inverse of drainage density as a property termed as constant of channel maintenance. Similar to the drainage density, constant of channel maintenance depends on the basin relative relief, lithology, climate, etc. It decreases with increasing erodibility (Schumn, 1956). Constant of channel maintenance $(\mathrm{C})$ value for Maniari

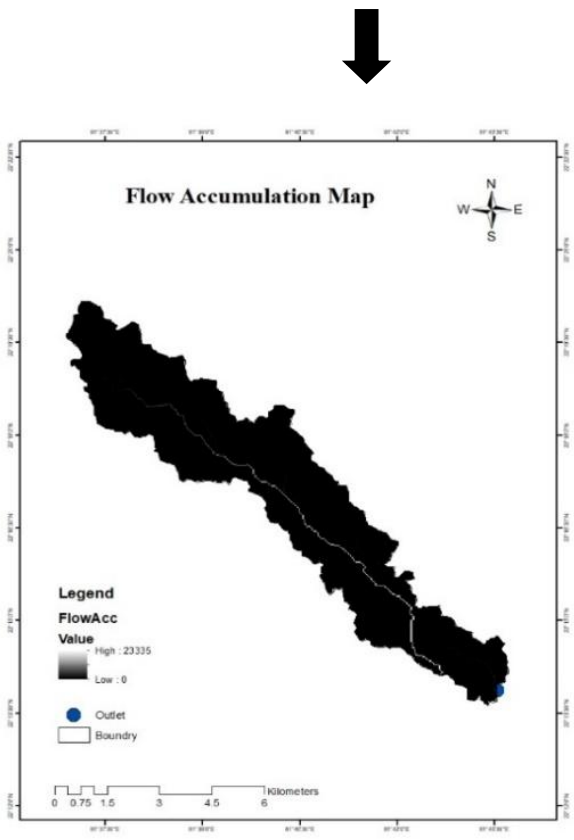

sub-watershed was found to be 0.59 . Higher values suggest more area is required to produce surface flow which implies that part of water may get lost by evaporation, percolation etc., lower value indicates less chances of percolation/infiltration and hence more surface runoff (Bhagwat et al., 2011).

In conclusion, GIS and Remote sensing techniques have proved to be accurate and 
efficient tool in drainage delineation and their updation. The study seeks to utilize the interpretation capabilities of GIS to find out the morphometric parameters of Maniari subwatershed. Further, the Remote Sensing techniques have been found to be suitable for the preparation of updated drainage map in a timely and cost-effective manner and should be preferred in soil erosion studies for deriving input data. The analysis of morphometric parameters at river basin helps us to understand the relationships among the different aspects of the drainage patterns and their influence on land forming processes, drainage, and land erosion properties. The drainage density and stream frequency are the decisive factor for the morphometric classification of drainage basins. These are the factors which describe the runoff pattern, sediment yield and other hydrological parameters of the drainage basin. The subwatershed consists of 4th order stream network with total length of stream is 52.788 $\mathrm{km}$ and drainage density $1.684 \mathrm{~km} \mathrm{~km}^{-2}$ of the watershed, which shows that low drainage density nature of basin. Thus, these studies are very useful for planning and drainage basin management.

\section{References}

Agarwal CS (1998) Study of drainage pattern through aerial data in Naugarh area of Varanasi district, U.P. J Indian Soc Remote Sens 26:169-175

Bhagwat, T.N., Shetty, A. and Hegde, V.S. 2011. Spatial variation in drainage characteristics and geomorphic instantaneous unit hydrograph (GIUH); implications for watershed management- A case study of the Varada River basin, Northern Karnataka. Catena 87: 52-59.

Biswas, S., Sudhakar, S. and Desai, V.R. (1999) Prioritization of Sub-Watersheds Based on Morphometric Analysis of drainage basin: A Remote Sensing and GIS approach, Journal of Indian Society of Remote Sensing, 27(3), pp 155-166.

Chorley, R.J., Donald, E.G., E.G. Malm, P.H.A. (1957) "New standard for estimating drainage Basin Shape" American Journal of Science 255: 138141.

Clarke JI (1996) Morphometry from Maps. Essays in geomorphology. Elsevier publication. Co., New York, pp 235274

Horton, R. E.1932. Drainage basin characteristics, Trans. Am. Geophys. Unon.13: pp 350-361.

Horton, R.E. 1945. Erosional development of streams and their drainage basins; Hydro physical approach to quantitative morphology. Bulletin of Geological Society of America, 56, 275-370.

Javed, A., Khanday, M.Y. and Rias, S. (2011) Watershed Prioritization Using Morphometric and Land Use/Land Cove Parameters: A Remote Sensing and GIS Based Approach. Journal Geological Society of India, 78, 63-75.

Kanth, T.A., Hassan, Z.U. (2012) Morphometric analysis and prioritization of watersheds for soil and water resource management in Wular Catchment using Geo-Spatial Tools" International Journal of Geology, Earth and Environmental Sciences 2: 30-41. 2012

Miller, V.C., 1953. A quantitative study of drainage basin characteristics in the mountain area. Virginia and Tennessee. Technical report. Office of Naval research, Department of Geology, Columbia University, New York.

Nag, S.K. (1968) Morphometric analysis using remote sensing techniques in the Chaka subbasin Purulia district, West Bengal" Journal of Indian Society of Remote Sensing 26, 69-76.

Nautiyal, M. D., 1994. Morphometric analysis 
of a drainage basin, District Dehradun, Uttar Pradesh. J. Indian Soc. Remote Sens. 22, 251-261.

Nookaratnam, K., Srivastava, Y.K., Venkateswarao, V., Amminedu, E., Murthy, K.S.R. (2005) Check dam positioning by prioritization of microwatersheds using SYI model and morphometric analysis-remote sensing and GIS perspective" Journal of the Indian Society of Remote Sensing 33 (1), 25-38.

Patel, D., Gajjar, C. and Srivastava, P. (2013) Prioritization of Malesari MiniWatersheds through Morphometric Analysis: A Remote Sensing and GIS Perspective. Environmental Earth Sciences, 69, 2643-2656.

Schumn, S.A., 1956. Evolution of drainage systems and slopes in badlands at Perth, Amboy, New Jersey. Geological Society of America, Bulletin. 67, 597646.

Singh, S., Singh, M.C. (1997) Morphometric analysis of Kanhar river basin. National Geographical” J. India, 43 (1):31-43. 1997.

Strahler, A. N. (1964). Quantitative geomorphology of drainage basins and channel networks. In: Chow V.T. (ed.), Handbook of Applied Hydrology. McGraw Hill Book Company, New York Thornbury, W.D. 1969. Principles of Geomorphology. 2nd edition, Wiley and Sons, New York, USA.

Strahler, A., 1957. Quantitative analysis of watershed geomorphology. Transaction AGU 38, 913-920

Vijith, H., Satheesh, R. GIS based morphometric analysis of two major upland subwatersheds of Meenachil river in Kerala. Journal of Indian Society of Remote Sensing, 2006, Vol.34, No. 2. pp.181- 185.

Zavoiance, I. 1985. Morphometry of drainage basins (Developments in water science), Elsevier Science, New York, USA.

\section{How to cite this article:}

Shruti Verma, Dhiraj Khalkho and Lov Kumar Gupta. 2020. Morphometric Analysis of a Drainage Basin using Remote Sensing and Geographical Information System (GIS). Int.J.Curr.Microbiol.App.Sci. 9(04): 1950-1959. doi: https://doi.org/10.20546/ijcmas.2020.904.232 